\title{
Status and problems of apiculture in Baghpat District of Uttar Pradesh-A Survey
}

\section{Pukhraj Singh, Rashmi Nigam ${ }^{1^{*}}$, Nitin Kumar Nagand and Lalit Kumar Verma}

Deptt. of Agril. Economics, and ${ }^{1}$ Deptt. of Plant Pathology, J.V. College, Baraut, UP

*Email: neelu.nigam@gmail.com

\begin{abstract}
Apiculture as a village industry is of considerable importance but in study area it requires a lot of improvement in apicultural as well as in agricultural practices. Most of the beekeepers are facing problems due to lack of knowledge of bee management technology and related skills. This small cottage industry may be called in infancy in Baghpat district of Uttar Pradesh. Two villages selected from Baghpat district picked through convenience sampling to understand and compare the prospects of apiculture and information was acquired through questionnaires, observation and personal interviews.
\end{abstract}

Keywords: Apiculture, pollination, Queen rearing.

Paper cited: Singh, P., Nigam, R., Nagand, N.K. and Verma, L.K. (2018). Status and problems of apiculture in Baghpat District of Uttar Pradesh. South Asian Journal of Food Technology and Environment, 4(2): 745-747.

\section{Introduction}

Apiculture commonly known as beekeeping is the maintenance of artificial bee hive colonies with the objective of producing honey and it's by- products. "Bee" is the second largest topic of research after humans. India is an agricultural economy. Apiculture is the practice of keeping and managing honey bees, which contribute immensely to the welfare and economy of mankind. Honeybees not only provide honey, bees wax, royal jelly, and bee venom which are useful products from medical and commercial point of view but also play a vital role in pollination of various fruits \& crops. Apiculture also proves as an additional source of income with low investments and high returns. Moreover, Honeybees are the only insects that provide food for humans. The present study survey report reveals the problems being faced by apiculture in Baghpat district of Uttar Pradesh.

The present research work was carried out in Baghpat district of Uttar Pradesh, which is situated at latitude $28^{\circ} 57^{\prime} \mathrm{N}$, longitude $77^{\circ} 13^{\prime} \mathrm{E}$ and elevation above the sea level of Baghpat district is 253 meter. The district in spread over $1321 \mathrm{sq}$. km having 132100 hectare of land, out of which 108000 hectare is under cultivation. Baghpat district is also one of the most productive districts in the Sugarcane production. The major crops grown in the district are sugarcane, paddy, wheat, maize, potato, oilseeds and pulses.

South Asian J. Food Technol. Environ., 4(2): 745-747(2018)
Horticulture occupies an important place in the district. Mango, guava, peach, and papaya are the important fruits of the district. The district is famous for the cultivation of cucurbits other than potato, onion, okra, chili, vegetable pea and tomato. The climatic conditions of the district are highly suitable for floriculture, apiculture and mushroom cultivation. The soil of the district as a whole is very fertile and $99 \%$ area under cultivation is irrigated. The average annual rainfall of Baghpat district is $768.0 \mathrm{~mm}$; about $90 \%$ of rainfall takes place from June to September. The main commercial activities of the people living in this region is making and selling Gur and Khandsari Sugar, which is an agro-based industry. Apart from this, there are certain units which are involved in the making in agricultural equipments.

\section{Materials and Methods}

Detailed surveys have been made in the study area from year 2016-17 to collect information regarding status and problems of apiculture. Questionnaires were prepared and data was collected according to standard method from randomly selected beekeepers and their apiaries. Information regarding crop pattern, horticulture, tree cover and metrology was collected from related departments of Uttar Pradesh State. 


\section{Results and Discussion}

Lack of crop diversification: Continuous blooming forage is necessary for successful beekeeping, which is not possible without crop diversification. Dominating crop rotation in this area is wheat (Triticum aestivum) and paddy (Oryza sativa). On an average (from year 20016 to 2017) area under paddy and wheat was 10626 and 107843 ha respectively. This crop rotation is not very useful for beekeeping. Other crops which are considered good for apiculture are shown on very less area. Average area under Mustard crops, Til (Sesamum indicum. L.) and Arhar (Cajanus cajan) was only 1963, 07 and 536 hectare respectively.

Less area under tree cover: There is no true forest. Area under the tree covers in less than 5 percent. Trees of bee interest are Eucalyptus, Shisham, Kikar, Jaman, Arjun, Sirus and Shitootetc are grown on sides of roads, canals, drains and other places which are under the control of forest department. About 106 hectare of Eucalyptus has been planted by different farmers of this district.

\section{Floral scarcity/Dearth period}

There are totally dearth period in the month of May and June .The crop rotation are such that fields are empty from mid April to end of May. Farmers prepare soil for next crop season. Bee colonies have to be fed with sugar syrup. Some beekeepers also use pollen substitute. Strength of bee colonies in reduced to half. Only after rainfall, weeds of bee interest grow, which include. Rose, Marigold, Cuddle, Kaner, Cone flower, Black - eyed susan, Gladiolus, Aster etc. In the month of October and November there is floral scarcity again.

Excessive use of chemicals in Agriculture: Pesticides, fungicides \& weedicides etc., when applied to blooming orchard crops caused severe damage to honey bees. Sudden appearance of largest number of dying bees at the entrances of bee colonies could be observed in various apiaries of this area during flowering season of different crops, which in indication of pesticide poisoning. Such poisoned bees showed uncoordinated movements, became paralytic and loose the power of orientation .It has been observed that Lindane 10G (gamma-hexachlorocyclohexane) \& Phosalone 35 EC. Is comparatively safe when sprayed to crops late in the evening as confirmed by many workers? Use of bee repellents to discourage them from foraging on the pesticide treated crops, are not in practices.

Honeybee diseases, pests and enemies: Honeybees like all other creatures suffer from many diseases and are attacked by various parasites, pests and enemies. Nosema disease has been observed in many apiaries. Pests like lesser wax moths, Greater wax moth and Hawk moth were present. Losses due to wax moth (which is pest of all honeybees) were found serious as they destroy raised combs in storage as well as in hives, particularly during and after monsoon when colony strength is low .Similar type of observation were recorded by many workers. Predators included wasps, green bee eater birds and block drango. Other minor enemies include spiders, toads, ants and lizards etc.

Examinations of colonies : Examinations of hive at a regular interval are necessary to observe their conditions and requirements, diverse it may cause economic losses in the form of swarming and laying workers etc. Information's collected from different apiaries of Baghpat district showed that usually inspection operations are delayed. Only 22 percent of beekeepers perform examination of colonies in proper way.

Bee Nutrition: During dearth period sugar syrup and pollen substitute should be given to the bee colonies. But beekeepers of this area give only provide sugar syrup. Pollen substitute is provided by very low percent of beekeepers. There are shortages of pollen in one or another part of year. Natural pollen can be collected by using pollen traps, when pollen income in suitable (from mid January to mid March). This collected pollen can be preserved and may be used during pollen shortage periods. This technique is not being used. About 95 percent beekeepers do not know how to collect \& preserve pollen.

Queen Rearing: Grafting technique in the best method of queen rearing ,but less than 5 percent beekeepers use this method. The method used by most of them is formation of queen cells by simply dequeening the colonies which is a disadvantageous practice, Thus beekeepers get poor quality queens and looses more time with respect to egg laying and brood rearing which give a big setback. Only 2 per cent beekeepers did selected breeding .A commercial beekeeper must always store surplus mated queens in small nuclei but on an average only 2 per cent beekeepers followed this practice. 
Hive Products: Most of the beekeepers know honeybees for honey. They have negligible information regarding other hive products like royal jelly, propolis, bees wax and pollen etc. This honey yield is quite low. Other products are not extracted by beekeepers. Efforts should be made to educate the beekeepers about the use and importance of all Honey bee products.

\section{Recommendation}

To help in development of beekeeping industry in Baghpat district of Uttar Pradesh following recommendations is being made-

a. Farmers should be made aware regarding apiculture and pollination. Apiculture should be made an integral part of agricultural and horticultural techniques. Promotion of apiculture as an employment generation activity is the need of hour.

b. Diversification of crops is urgently required, so that period of floral scarcity may be decreased area under horticulture, vegetables must be increased.

c. Migratory beekeeping is suggested during dearth period .Sugar syrup and pollen substitute should be given at proper time.

d. Colonies must be kept strong as such colonies can win over every disease and enemies like wax moth etc.

e. Proper management techniques should be followed.

f. Queens must be reared by grafting method. Selective breeding is also necessary to improve the honeybee stock. Surplus mated queens in small nuclei must be maintained.

g. Processing of the honey should be done.

$\begin{array}{ll}\text { Received } & \text { : Oct., } 2018 \\ \text { Revised } & \text { : Nov., } 2018 \\ \text { Published } & \text { : Dec., } 2018\end{array}$

